\title{
Textural characteristics of sea ice and the major mechanisms of ice growth in the Weddell Sea
}

\author{
M.A. LANGe AND H. Eicken \\ Alfred-Wegener-Institut für Polar- und Meeresforschung, D-2850 Bremerhaven, Germany
}

\begin{abstract}
We report on studies of sea-ice texture conducted during a number of expeditions into the Weddell Sea. Sea ice in the Antarctic is dominated by granular ice of frazil origin in floes of all ages, in contrast to ice in the Arctic, which consists predominantly of columnar ice of congelation origin. The large fraction of granular ice in first-year sea ice is a result of the dominant ice-formation process in the advancing ice edge, the pancake cycle. The dominance of granular over columnar ice in second- and/or multi-year ice is a result of the large degree of deformational activity in the Southern Ocean.
\end{abstract}

\section{INTRODUCTION}

Sea-ice texture, i.e. the geometry and spatial arrangement of ice crystals and air- or brine-filled pore-space, represents a key parameter in the understanding of a number of seaice characteristics. Ice texture is correlated with/or controls ice properties (e.g. the mechanical strength) and the profiles of major chemical and biological parameters (e.g. salinity and the distribution of micro-organisms) in an ice core. However, texture also holds the key to unravelling the history of formation and evolution of the ice. Thus, analyses of ice texture and the definition of the stratigraphy of a core lead to a better comprehensive understanding of the sea-ice development and the interdependence of different ice properties.

Ice texture has been studied in considerable detail in the Arctic (e.g. Weeks and Ackley, 1982; Gow and others, 1987b). Based on these observations, a "standard model" of sea-ice growth and development has been proposed. In this model, sea-ice growth begins with the formation of suspended ice crystals at the surface of the supercooled top layer of the ocean to produce frazil or slush ice (Weeks and Ackley, 1982). After a layer of slush consolidates and forms an initial, solid ice cover, growth rates drop significantly and subsequent growth occurs via congelation at the ice/ water interface. Thus, below the initial layer of frazil ice, which is characterized by a granular texture and a thin layer of mixed granular/columnar ice, is a zone of pure columnar ice (for details of textural classification, see Eicken and Lange, 1989; Lange and others, 1989). The $c$ axes of the columnar grains become more and more aligned in the horizontal and the grain-sizes increase with increasing depth. Consequently, the textural distribution should be dominated by columnar ice with horizontally aligned $c$ axes, as has been observed in the Arctic.

Gow and others (1987b) found 75\% congelation versus $25 \%$ frazil ice in a large number of cores obtained in Fram Strait. However, the first systematic investigations of sea ice in the Weddell Sea, on the U.S. icebreaker Polar Sea, revealed quite a different picture than was expected based on the "Arctic model" in that the Antarctic sea ice was characterized by a much larger fraction of frazil, compared to congelation ice (Gow and others, 1982, 1987a; Weeks and Ackley, 1982).

With advances in icebreaker technology and the availability of ice-going research vessels in recent years, it became possible to observe and sample the winter sea-ice cover, which had previously been almost inaccessible.

During the last four years, we have undertaken a number of expeditions into the Weddell Sea on F.S. Polarstern, both during winter and during late winter/early spring. In our field and laboratory analyses, we have concentrated on textural studies and their relations to other sea-ice properties (see Lange, 1988). In the present paper, we will address the following questions, based on results of these studies:

(i) What are the overall textural characteristics of sea ice in the Weddell Sea?

(ii) What is the fraction of frazil versus congelation ice in Antarctic sea ice?

(iii) What are the major growth processes of Weddell Sea ice?

\section{FIELD WORK/ANALYTICAL TECHNIQUES}

Figure 1 shows the study areas of our expeditions on F.S. Polarstern during 1986 and 1988, as well as the cruise track of the 1989 expedition. Also shown is the study area of the Polar Sea expedition. In addition, the 1986 Polarstern study area overlapped that covered by the $M$. Somov in late winter 1981 (not shown). Results of the sea-ice investigation during the latter expedition are given in Clarke and Ackley (1984).

At daily ice stations we obtained a number of ice cores, measured snow and ice thicknesses in at least 100 


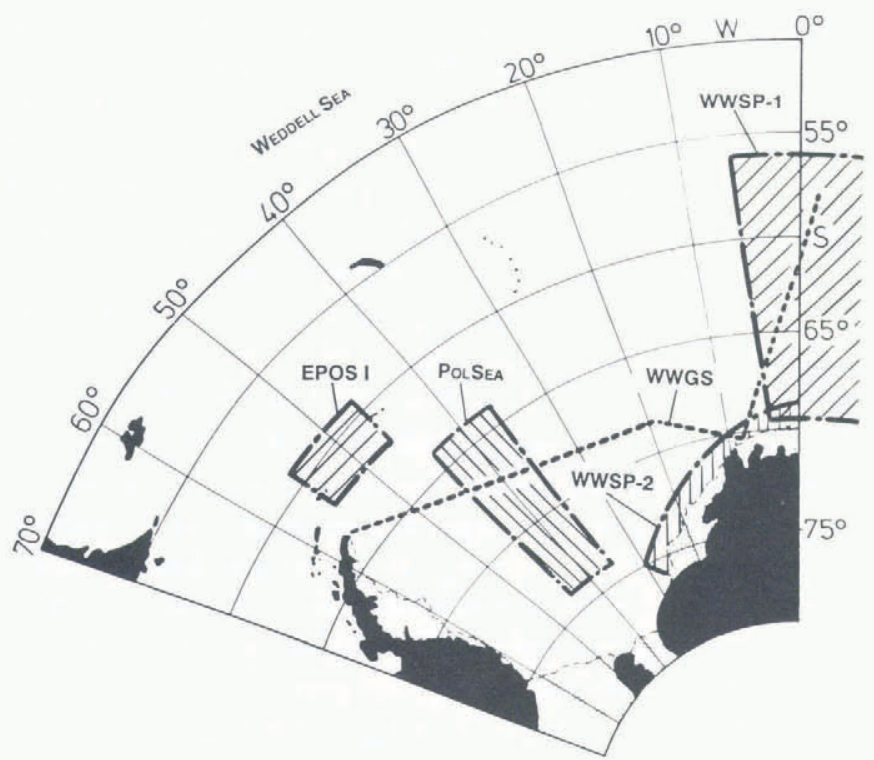

Fig. 1. Study areas and cruise track of Polarstern expeditions as well as the Polar Sea expedition in the Weddell Sea.

(and up to 200) mechanically drilled holes and analyzed the surface properties along a standard grid of approximately 15 by $15 \mathrm{~m}$ (Lange, 1989). During the vessel's traverse through ice-covered waters, hourly observations of general ice conditions were performed. They were supplemented by helicopter reconnaissance flights and still- and video-photography.

Ice cores were analyzed in a mobile cold laboratory on board the Polarstern. Thick sections were cut along the entire length of the cores and analyzed for texture. This resulted in a continuous core stratigraphy, which served as the basis for subsequent sampling and analyses (for details, see Lange, 1988). Whenever assignment of textural classes was questionable, thick sections were supplemented by vertical and horizontal thin sections. In our analyses, we distinguish between five textural classes (Eicken and Lange, 1989; Lange and others, 1989) which are believed to be indicative of particular growth processes of the ice cover. For each core, the relative proportions of granular and columnar ice were determined and were used subsequently to assign a genetic class to each core (Eicken and Lange, 1989; Lange and others, 1989). Genetic ice classes characterize the growth and development of a floe or at least the section of a floe under study. Major genetic ice classes, which are central in the present study, are frazil and congelation ice.

In addition to determining the fraction of granular versus columnar ice in each core, we established a number of textural parameters for cores from each expedition. We were thus able to distinguish between different regions (i.e. a central and a south-eastern region for the second leg of the Winter Weddell Sea Project, WWSP-2 and WWSP$2_{\text {se }}$, respectively) and between first- and second-year ice for the EPOS-I cruise. In particular, we determined the mean length of retrieved cores, $L_{\mathrm{M}}$, and the mean fraction of columnar ice, $C_{\mathrm{M}}$, for each expedition. We also obtained the mean lengths of stratigraphic units, $t_{\mathrm{M}}$, and the mean ratio, $R_{\mathrm{M}}$, of the number of textural units in the top versus the bottom halves of cores.
Table 1. Observed sea-ice textures during a number of expeditions into the Weddell Sea

\begin{tabular}{|c|c|c|c|}
\hline \multirow[t]{2}{*}{ Expedition ${ }^{1}$} & \multicolumn{2}{|c|}{ Observed growth } & \multirow{2}{*}{ Authors } \\
\hline & zil, $\%$ & gelatior & \\
\hline PolSea & 57.4 & 42.6 & $\begin{array}{l}\text { Gow and others, } \\
1987 a\end{array}$ \\
\hline Somov & 69.5 & 30.5 & $\begin{array}{l}\text { Clarke and } \\
\text { Ackley, } 1984\end{array}$ \\
\hline WWSP-1 & 57.1 & 42.9 & $\begin{array}{l}\text { Lange and others, } \\
1989\end{array}$ \\
\hline WWSP-2 & 51.7 & 48.3 & $\begin{array}{l}\text { Eicken and } \\
\text { Lange, } 1989\end{array}$ \\
\hline EPOS-I & 63.8 & 36.2 & Lange, 1989 \\
\hline WWGS & 41.9 & 58.1 & Unpublished \\
\hline
\end{tabular}

$\begin{array}{lll}\text { Mean } & 56.9 \quad 43.1\end{array}$

Standard

$\begin{array}{lll}\text { deviation } & 8.7 & 8.7\end{array}$

${ }^{1}$ PolSea $=$ Polar Sea Expedition; Somov $=$ Weddell Polynya Expedition on NES M. Somov; WWSP = Winter Weddell Sea Project (Leg 1 and 2); EPOS-I = first leg of the European Polarstern Study; WWGS = Winter Weddell Gyre Study.

\section{RESULTS AND DISCUSSION}

Table 1 shows the overall fraction of frazil versus congelation growth as seen in the initial study by Gow and others (1987a) and by Clarke and Ackley (1984), as well as in our expeditions. The table indicates clearly that, with the exception of the Winter Weddell Gyre Study in 1989, frazil ice has been more commonly observed than has congelation ice. In the course of the latter expedition, we found a large number of refrozen leads. The textural distribution of the ice in these leads was dominated by relatively thin, columnar ice of congelation origin.

The detailed textural analyses for each of our expeditions (except for WWGS) are given in Table 2.

Table 2. Stratigraphic data for ice cores from different expeditions. $\quad\left(L_{\mathrm{M}}=\right.$ mean core length; $C_{\mathrm{M}}=$ mean fraction of columnar ice; $t_{\mathrm{M}}=$ mean length of stratigraphic units; $R_{\mathrm{M}}=$ mean ratio of the number of stratigraphic units in the top versus the bottom halves of cores; $\mathcal{N}=$ total number of analyzed cores)

\begin{tabular}{llllll}
\hline Expedition $^{1}$ & $\begin{array}{l}L_{\mathrm{M}} \\
(\mathrm{m})\end{array}$ & $\begin{array}{c}C_{\mathrm{M}} \\
(\%)\end{array}$ & $\begin{array}{c}t_{\mathrm{M}} \\
(\mathrm{m})\end{array}$ & $R_{\mathrm{M}}$ & $\mathcal{N}$ \\
\hline WWSP-1 & 0.66 & 30.6 & 0.17 & 1.7 & 39 \\
WWSP-2 & 0.59 & 14.2 & 0.26 & 1.3 & 10 \\
WWSP-2 & 0.83 & 53.4 & 0.59 & 1.4 & 22 \\
EPOS-I (1st year) & 0.71 & 31.2 & 0.23 & 2.0 & 10 \\
EPOS-I (2nd year) & 2.00 & 35.9 & 0.42 & 1.8 & 21 \\
\hline
\end{tabular}

${ }^{1}$ For an explanation, see Table 1 and text. 
The overall core lengths (i.e. ice thicknesses) are small compared to Arctic sea ice. (First-year ice in the Arctic has a mean thickness of about $1.5 \mathrm{~m}$ (Maykut, 1986).) This finding is confirmed by sea-ice thickness studies reported by Wadhams and others (1987) and Lange and Eicken (in press). The mean fraction of columnar ice seen in our cores lies at or below $30 \%$, with the exception of ice found during the second leg of the Winter Weddell Sea Project in the southeastern Weddell Sea (WWSP-2 se $_{\text {) }}$. This region is dominated by the opening and closing of coastal polynyas during the winter months, depending on the direction and strength of surface winds. In the absence of a significant wave field, an open polynya freezes over rapidly through the formation of congelation ice. Subsequent wave motions and southerly surface winds lead to the advection of sea ice to the north and to substantial rafting. Thus, when sampling the resulting floes, they will contain a sizable fraction of columnar ice of significant thickness (often two rafted columnar sheets become indistinguishable by thick section analyses), as seen in Table 2 .

The mean lengths of stratigraphic units show a large variation between different expeditions, but seem to be fairly uniform (at around 0.2 to $0.3 \mathrm{~m}$ ) in first-year sea ice. Here again ice in the southeastern part of the Weddell Sea is an exception, with relatively thick uniform stratigraphic units. In contrast, stratigraphic units of second-year ice, as seen during the EPOS-I cruise, are about twice as thick as

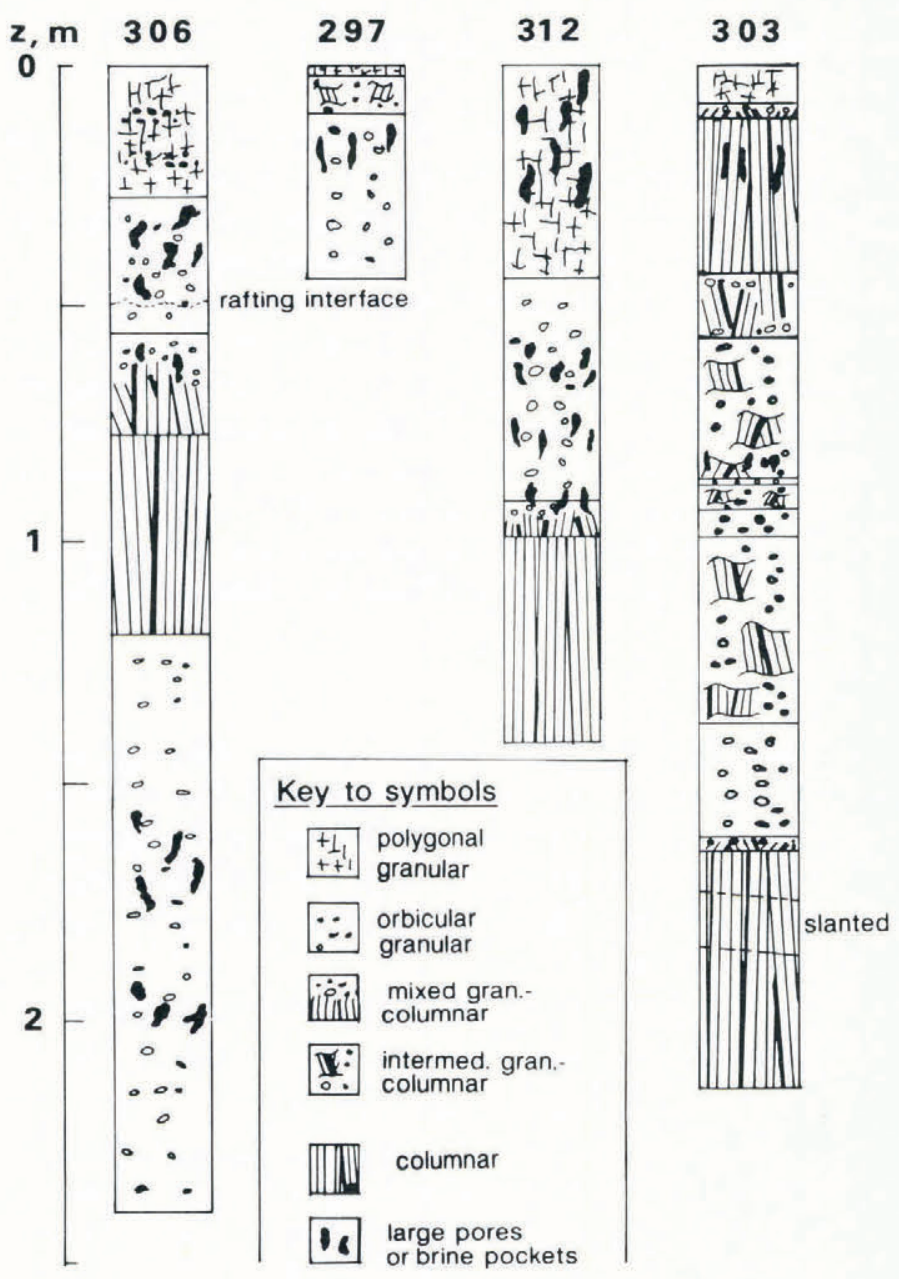

Fig. 2. Stratigraphies of ice cores versus depth, $z$, obtained during the EPOS-I expedition in the northwestern Weddell Sea. The core numbers are given at the top of each profile. their first-year counterparts. The ratio of the numbers of stratigraphic units in the top to bottom half of the cores, $R_{\mathrm{M}}$, is uniformly larger than one, indicating that "orderly" congelation growth dominates in the second half of the growth cycle. Alternatively, this result could indicate that, with increasing thickness, rafting of floes is reduced, resulting in a more uniform textural distribution.

Figure 2 provides four typical examples of rafted and undeformed first-year ice floes and of undeformed and deformed second-year ice floes, respectively (from left to right). In order to assign ages to each core, we used a combination of parameters from our ice-core analyses, as well as from the surface snow observations (for details, see Eicken and others, in press). The stratigraphies illustrate the complexity of sea-ice development in Antarctic waters. Our observations lead us to conclude that, unlike the Arctic, sea-ice development in Antarctica is dominated by a high degree of rafting and ridging activities.

Another important finding in our studies is the large mean fraction of frazil ice in second- and/or multi-year sea ice (Table 2). Only about $36 \%$ of the second-year ice consists of columnar ice while granular ice comprises the dominant textural unit. Thus, unlike in the Arctic, growth in the Antarctic, even after one summer, appears to be dominated by frazil rather than by congelation growth. This finding has been confirmed by results from the more recent Winter Weddell Gyre Study (unpublished).

We suggest that the large degree of deformational activity, as evident in the stratigraphy of our cores, is a major reason for the observed textural distribution. Frequent ice deformation prevents the orderly congelation growth (i.e. columnar texture) seen in Arctic sea ice (Fig. 3).

We recognize four components in deformation-related ice growth:

(i) As a result of ridging activities, brash and newly formed frazil appear at arbitrary places within cores, regardless of the original texture. These contributions of frazil ice are observable relatively easily in the core stratigraphies (highly nonuniform texture).

(ii) Ice deformation, particularly rafting events, leads to new open-water areas which are covered quickly by a slush-ice layer of frazil origin. Subsequent rafting will deposit this layer underneath existing floes and will lead to granular sections underlying columnar ice sections (see Fig. 2, core 303, at approximately $1 \mathrm{~m} \mathrm{depth).}$

(iii) Rapid ice formation in leads results in salt expulsion and convective overturn of the surface water layer, resulting in cold, salty surface water sinking to greater depths. During this transport, salt and heat will be exchanged with the surrounding water. However, since salt diffusion proceeds faster than the exchange of heat, the sinking surface water becomes increasingly supercooled and frazil formation sets in (double diffusion; for details see Weeks and Ackley, 1982). A fraction of this frazil ice will be deposited underneath existing floes, giving rise to sizable sections of granular ice underneath preexisting columnar ice (see Fig. 2, core 306, below approximately $1.2 \mathrm{~m}$ ). 

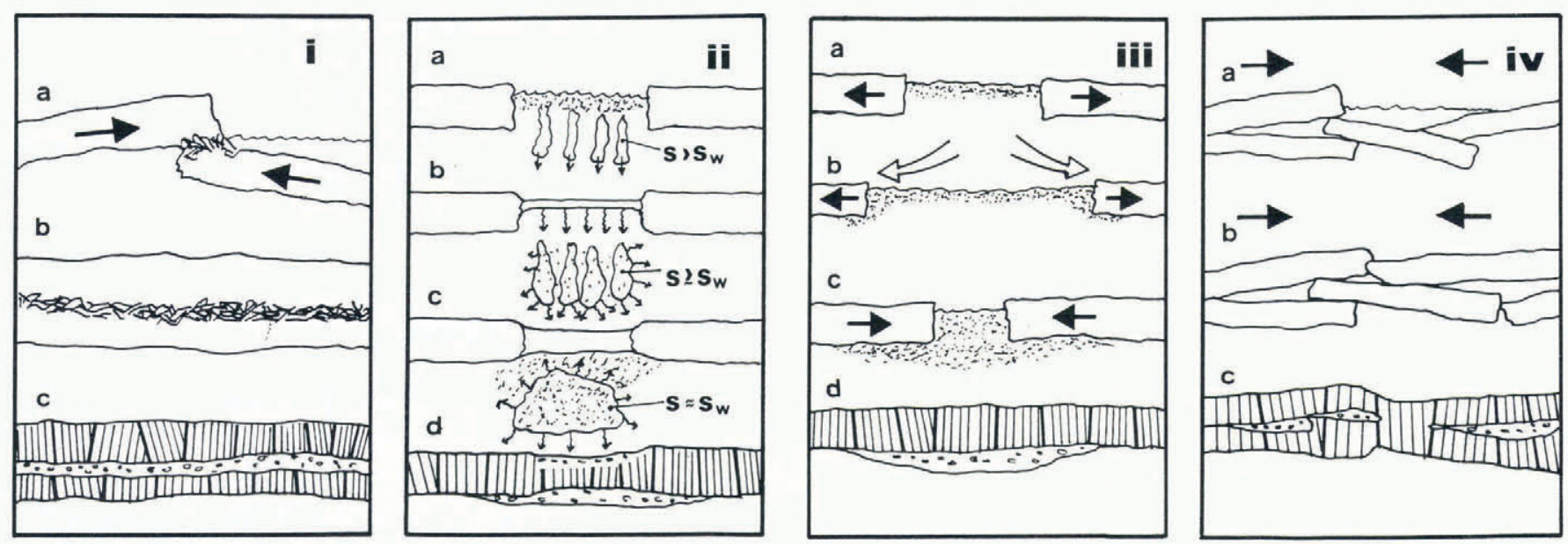

Fig. 3. Schematic representation of deformation-related processes that lead to the observed large fraction of frazil ice in first-or second-year ice. The four panels depict: (i) frazil formation due to brash ice, formed through rafting and ridging of floes; (ii) rapid frazil growth at the sea surface in newly derived leads; (iii) frazil formation due to double diffusion as a result of rapid ice growth in leads; (iv) growth of frazil in gaps and voids of rafted floes (the letters a-d depict subsequent temporal states of the ice cover; for further details, see text).

(iv) Finally, the gaps between two rafted floes will normally be filled rapidly with frazil ice, thus also leading to interior portions of granular ice (see Fig. 2, core 306 , at $0.5 \mathrm{~m}$ ).

The fraction of congelation ice versus total core length for all ice cores from the different expeditions is shown in Figure 4. Whereas Gow and others (1987a) postulated a correlation between the fraction of congelation ice and total ice thickness, we do not find any significant correlation in our data. As can be seen, for total core lengths of up to about $2 \mathrm{~m}$, there is no definable trend in the congelation fraction versus core length in sea ice. For ice of more than $2 \mathrm{~m}$ length, i.e. primarily second- and/or multi-year ice, the congelation-ice fraction lies below $50 \%$. This supports our hypothesis that even in second-year ice, deformation-induced growth appears more important than "orderly" congelation growth.

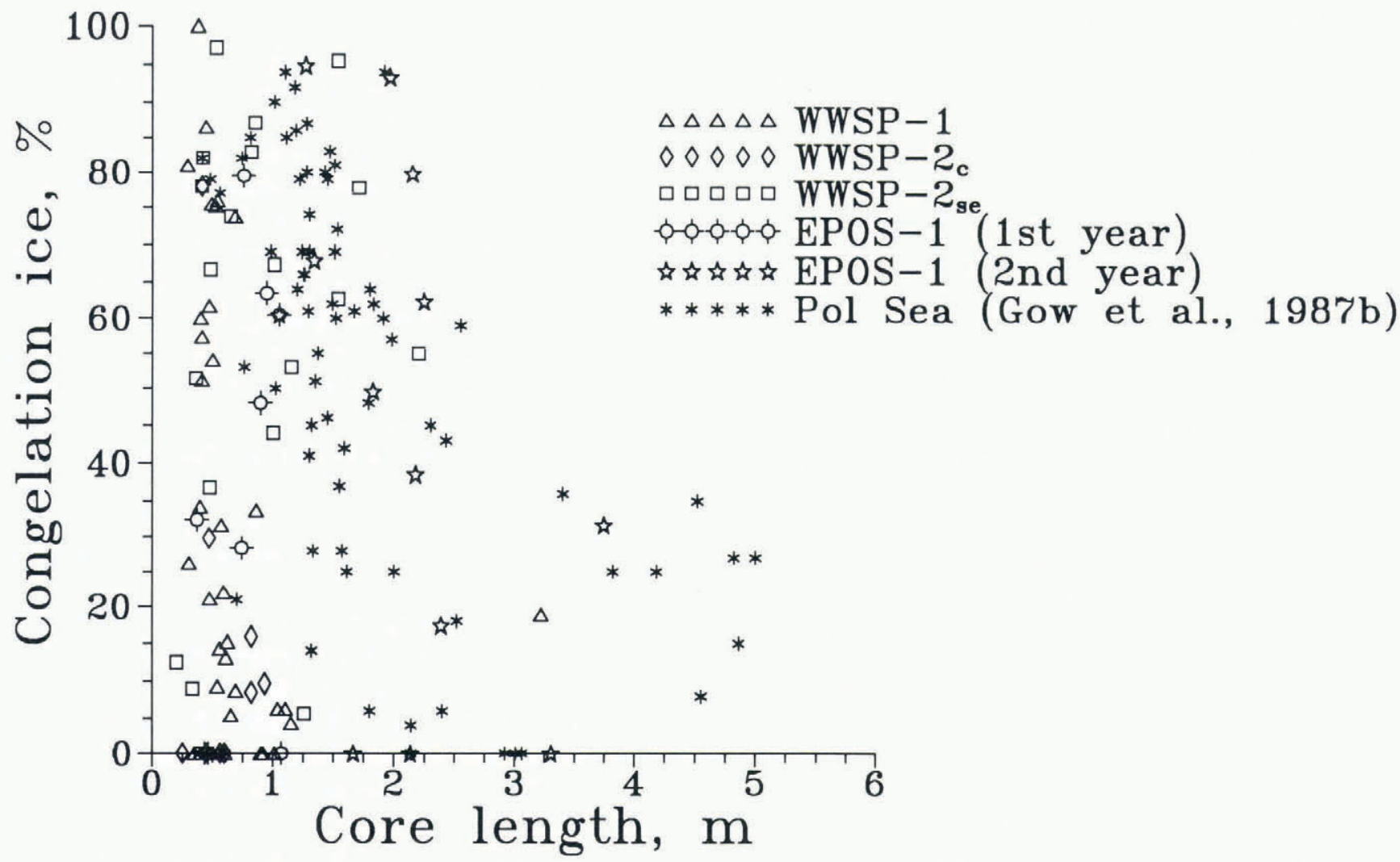

Fig. 4. Fraction of congelation ice versus core length in ice cores obtained during a number of expeditions (for an explanation of acronyms see Table 1 and text). 
The large proportion of frazil ice seen in first-year ice (Table 1; Fig. 2, core 297) is a result of the so-called pancake cycle, which is described in Lange and others (1989).

A final point to be noted in Figure 2 is the large fraction of polygonal granular ice in cores 306 and 312. As has been shown by Lange and others (1990), based on $\delta^{18} \mathrm{O}$ measurements on cores from WWSP-1, the fraction of snow-ice comprises a significant portion of the overall ice thickness in first-year ice in the Weddell Sea. In the absence of congelation growth, snow-ice formation remains as the major growth process of existing floes.

\section{CONGLUSION}

Sea ice in the Antarctic is dominated by granular ice of frazil origin. This applies to first-year, second-year and multi-year sea ice. Whereas the large fraction of frazil ice in first-year ice is mainly a result of the pancake cycle, the dominance of frazil versus congelation ice in second-year ice can be attributed to deformational activity in the Southern Ocean.

Four processes of deformation-related frazil growth lead to granular ice sections between or underneath columnar ice. Aside from these processes, rafting of undeformed frazil-ice floes underneath ice floes dominated by columnar ice will also lead to the observed stratigraphies.

A surprising result of our studies is the observation of a significant fraction of snow-ice of up to $16 \%$, i.e. surface snow metamorphosed and re-textured in the presence of sea water (for details see Lange and others, 1990). Snowice is detected by its textural characteristics, as well as by negative $\delta^{18} \mathrm{O}$ values. In contrast, equilibrium fractionation during freezing of sea water will lead to positive $\delta^{18} \mathrm{O}$ values of $2-3 \%$. As has been shown, snow-ice formation seems to be a very common process in the Antarctic (Lange and others, 1990). This is supported by our thickness data, which indicate that large parts of the sampled floes are characterized by negative freeboards, i.e. the ice-water interface lies below the water line. This is one of the prerequisites for snow-ice formation (Wadhams and others, 1987; Lange and Eicken, in press).

In summary, our findings demonstrate that sea-ice formation in the Antarctic differs to a large extent from processes observed in the Arctic. First-year growth in the Antarctic is moderate compared to the Arctic. Mean thicknesses of 0.4 to $0.6 \mathrm{~m}$ in the Weddell Sea (Wadhams and others, 1987) compare with a mean thickness of $1.5 \mathrm{~m}$ in the Arctic (Maykut, 1986). Due to large oceanic heat fluxes (Gordon and Huber, 1990), congelation growth underneath ice floes formed via the pancake cycle is minimal. Thus, once a pancake floe has been formed, its thickness changes little in the course of the winter. In the near absence of congelation growth, snow-ice formation comprises a significant process of ice growth in Antarctic waters (Lange and others, 1990).

The subsequent development of sea-ice floes is dominated by deformational events (rafting and ridging), which lead to highly varying stratigraphies, dominated by granular ice of frazil origin. This is in contrast to the more "orderly" congelation growth which follows the initial growth phase in the Arctic. One of the underlying causes of these differences lies in the unrestricted nature of the circum-Antarctic ocean, compared to the relatively confined Arctic Ocean. Whereas these facts have long been recognized, our results show that they do indeed greatly influence the properties of sea ice in the Antarctic.

\section{ACKNOWLEDGEMENTS}

We thank the officers and crew of Polarstern for help during the expeditions. Numerous people have also contributed in field and analytical work, which is greatly appreciated. We thank our colleagues, S. Ackley, P. Wadhams and G. Dieckmann for valuable discussions and S. Ackley and W. Weeks for constructive reviews. This work was supported by a grant of the Deutsche Forschungsgemeinschaft ( $\mathrm{La}$ 542/1). This is contribution no. 349 of the AlfredWegener-Institut für Polar- und Meeresforschung.

\section{REFERENCES}

Clarke, D.B. and S.F. Ackley. 1984. Sea ice structure and biological activity in the Antarctic marginal ice zone. $\mathcal{F}$. Geophys. Res., 89(C2), 2087-2095.

Eicken, H. and M.A. Lange. 1989. Development and properties of sea ice in the coastal regime of the southeastern Weddell Sea. 7. Geophys. Res., 94(C6), 8193-8206.

Eicken, H., M. A. Lange and G. S. Dieckmann. In press. Spatial variability of sea ice properties in the northwestern Weddell Sea. J. Geophys. Res.

Gordon, A.L. and B.A. Huber. 1990. Southern Ocean winter mixed layer. 7. Geophys. Res., 95(C7), 11,65511,672 .

Gow, A.J., S.F. Ackley, W.F. Weeks, and J.W. Govoni. 1982. Physical and structural characteristics of Antarctic sea ice. Ann. Glaciol., 3, 113-117.

Gow, A.J., S.F. Ackley, K.R. Buck, and K.M. Golden. 1987a. Physical and structural characteristics of Weddell Sea pack ice. CRREL Rep. 87-14.

Gow, A.J., W.B. Tucker, III, and W.F. Weeks. 1987b. Physical properties of summer sea ice in the Fram Strait, June-July 1984. CRREL Rep. 87-16.

Lange, M.A. 1988. Basic properties of Antarctic sea ice as revealed by textural analyses of ice cores. Ann. Glaciol., 10, 95-101.

Lange, M.A. 1989. Sea ice properties. Ber. Polarforsch. 62, 85-97.

Lange, M.A. and H. Eicken. In press. The sea ice thickness distribution in the northwestern Weddell Sea. 7. Geophys. Res.

Lange, M.A., S.F. Ackley, P. Wadhams, G.S. Dieckmann, and H. Eicken. 1989. Development of sea ice in the Weddell Sea. Ann. Glaciol., 12, 92-96.

Lange, M.A., P. Schlosser, S.F. Ackley, P. Wadhams, and G.S. Dieckmann. 1990. ${ }^{18} \mathrm{O}$ concentrations in sea ice of the Weddell Sea, Antarctica. J. Glaciol., 36(124), 315323.

Maykut, G.A. 1986. The surface heat and mass balance. In Untersteiner, N., ed. The geophysics of sea ice. New York, Plenum Press, 395-463. 
Wadhams, P., M.A. Lange, and S.F. Ackley. 1987. The ice thickness distribution across the Atlantic sector of the Antarctic ocean in midwinter. 7. Geophys. Res., 92(C13), $14,535-14,552$.
Weeks, W.F. and S.F. Ackley. 1982. The growth, structure and properties of sea ice. CRREL Monogr. 82-1.

The accuracy of references in the text and in this list is the responsibility of the authors, to whom queries should be addressed. 